\title{
Peran literasi ekonomi digital terhadap motivasi siswa dalam berwirausaha
}

\author{
Dewi Ayu Sakdiyyah*, Taruni Risla H \\ Universitas Negeri Malang, Jl. Semarang No. 5 Malang, Jawa Timur, Indonesia \\ *Penulis korespondensi, Surel: dewiayusakdiah@gmail.com
}

Paper received: 3-3-2021; revised: 24-3-2021; accepted: 28-3-2021

\begin{abstract}
Abstrak
Penulisan artikel ini bertujuan untuk mendeskripsikan peran literasi digital terhadap motivasi siswa dalam berwirausaha. Adapun dalam penelitian yang dilakukan oleh peneliti ini menggunakan metode studi pustaka, dimana temuan dan teori dari penelitian terdahulu digunakan sebagai dasar dalam menyusun artikel ini. Selanjutnya data yang diperoleh tersebut dianalisis atau dikaji secara mendalam dan terperinci sesuai dengan topik yang akan dibahas dengan memberikan penjelasan secara sistematis, logis, spesifik, dan konkret. Teknik analisis yang digunakan oleh peneliti adalah teknik analisis isi, yang mana teknik ini telah digunakan dan diterima untuk melakukan penelitian secara luas dalam ilmu sosial. Berdasarkan hasil analisis diperoleh informasi bahwasanya perkembangan teknologi yang semakin pesat saat ini, serta serta dengan adanya literasi ekonomi digital dalam pendidikan mampu meningkatkan minat siswa dalam berwirausaha, sehingga kedepannya diharapkan banyak siswa yang ketika keluar dari sekolah sudah memiliki kemampuan tertentu untuk dikembangkan dalam usahanya.
\end{abstract}

Kata kunci: literasi ekonomi; literasi digital; berwirausaha

\section{Pendahuluan}

Tantangan dan peluang yang disuguhkan di era revolusi industri 4.0 dan society 5.0 telah mendorong berbagai inovasi pendidikan dalam satu dekade terakhir (Bilotta dkk., 2020; Fukuda, 2019; Mourtzis dkk., 2020). Adapun pada era revolusi industri 4.0 yang diprakarsai oleh Pemerintah Jerman ini, ahli pendidikan menyebutkan bahwa proses pembelajaran berusaha memadukan teknologi siber dan teknologi otomatisasi (Aziz Hussin, 2018; Teo dkk., 2021). Adanya revolusi industri tersebut juga membuat kegiatan pendidikan dapat dilakukan melalui genggaman dengan memanfaatkan internet. Selain itu dari sisi guru juga banyak memperoleh referensi serta metode yang tepat untuk proses pembelajaran. Dalam proses pembelajaran, setidaknya terdapat empat kompetensi yang harus dimiliki oleh guru, diantaranya adalah keterampilan berpikir kritis untuk memecahkan masalah, keterampilan dalam berkomunikasi dan berkolaborasi, kemampuan berpikir secara kreatif dan inovatif, dan literasi terhadap teknologi dan informasi, dimana guru diharapkan mampu memanfaatkan berbagai referensi pada internet guna menunjang proses pembelajaran (Romijn dkk., 2021; Rubach \& Lazarides, 2021).

Sementara itu society 5.0 atau yang dikenal dengan masyarakat super pinter merupakan visi pemerintah Jepang yang diluncurkan pada bulan April 2016 lalu. Masyarakat super pintar dapat didefinisikan sebagai masyarakat baru dalam tahap kelima yang mengikuti empat tahap sebelumnya yakni masyarakat berburu, masyarakat agraris, masyarakat industri dan masyarakat informasi (Grunwitz, 2019). Pengembangan society 5.0 ini bertujuan untuk menciptakan masyarakat yang berpusat pada manusia, di mana produk dan layanan akan tersedia untuk memenuhi berbagai kebutuhan potensial, serta untuk mengurangi kesenjangan 
ekonomi dan sosial sehingga semua orang hidup nyaman dan bersemangat (Gladden, 2019). Visi tersebut didasarkan pada pengenalan tren global saat ini. Laju perkembangan ekonomi, teknologi, maupun sosial semakin hari semakin cepat.

Pesatnya perkembangan teknologi informasi dan komunikasi (TIK) dalam beberapa tahun terakhir telah membawa ledakan data digital yang belum pernah terjadi sebelumnya (Tarighi \& Shavvalpour, 2021). Selain itu, pesatnya globalisasi juga memperluas berbagai kegiatan ekonomi dan sosial di luar batas negara, dan juga telah mengubah proses penciptaan ide-ide baru dalam inovasi. Dapat diketahui bersama bahwasannya ide-ide baru yang dihasilkan melalui berbagai sumber tersebut secara signifikan berkontribusi pada keunggulan kompetitif (Saeidi dkk., 2019). Disisi lain, pesatnya perubahan dalam berbagai aspek baik ekonomi maupun teknologi tersebut membuat Negara Jepang melihat bahwa era revolusi industri 4.0 harus diimbangi dengan society 5.0 (Berawi, 2019). Hal tersebut merupakan usaha untuk membawa transformasi di luar industri dan untuk membangun masyarakat super pintar di mana teknologi, pengetahuan dan nilai-nilai baru terus diciptakan untuk berkontribusi pada pertumbuhan ekonomi dan kesejahteraan sosial. Lahirnya society 5.0 ini diharapkan tidak merubah peran pendidik dalam mengajarkan nilai-nilai moral yang telah ada selama ini, yang disebabkan oleh pesatnya perkembangan teknologi.

Pendidikan sebagai simbol kemakmuran suatu negara tampaknya sudah menjadi suatu hal yang tidak terbantahkan (Alam dkk., 2020). Pendidikan bisa menjadi sarana yang efektif dalam mensosialisasikan norma-norma, etos kerja, serta nilai yang ada dalam masyarakat. Sehingga dalam pendidikan, materi ajar yang diberikan harus sesuai dengan kebutuhan dimasa mendatang. Pendidikan ekonomi sebagai ilmu yang mengkaji tentang tingkah laku manusia dalam menggunakan berbagai sumber daya, hendaknya kurikulum yang diberikan pada siswa juga mengikuti perkembangan teknologi dan informasi (Suratno dkk., 2021). Pada dasarnya konsep dasar ilmu ekonomi sudah dimiliki oleh masing-masing individu, hal ini dikarenakan setiap individu mempunyai banyak kebutuhan yang berusaha untuk dipenuhi dalam rangka mencapai titik kepuasan. Meskipun konsep tersebut telah dimiliki oleh masing-masing individu, namun pendidikan ekonomi juga tetap penting untuk diberikan kepada siswa. Hal tersebut mengingat bahwa kebutuhan manusia bersifat tidak terbatas namun alat pemuas kebutuhan manusia bersifat terbatas, karena pada dasarnya jumlah alat pemuas yang tersedia di alam tidak sebanding dengan jumlah makhluk hidup yang tinggal didalamnya (Habibi \& Zabardast, 2020). Sehingga pendidikan ekonomi diberikan untuk mengatur manusia dalam mendayagunakan alat pemuas kebutuhan tersebut dengan tetap memperhatikan kondisi alam supaya tetap seimbang.

Pemahaman terhadap literasi ekonomi sangat penting untuk dimiliki oleh siswa sebagai generasi penerus bangsa (Suratno dkk., 2021). Literasi ekonomi dapat didefinisikan sebagai kecakapan seseorang dalam mengidentifikasi masalah-masalah ekonomi, dalam membuat keputusan yang tepat terhadap sumber daya yang ada, dengan mempertimbangkan biaya dan manfaat (Anggreini \& Waspada, 2020; Onis dkk., 2018). Selain literasi ekonomi, juga terdapat literasi digital yang tak kalah penting. Literasi ekonomi digital dalam penelitian ini merupakan gabungan antara literasi ekonomi dan literasi digital, yakni kemampuan dalam mengidentifikasi dan memanfaatkan informasi terkait ekonomi dari berbagai sumber dengan memanfaatkan teknologi (Moreno-Morilla dkk., 2021). Literasi ekonomi digital dapat dibangun melalui pendidikan, mengingat dalam pendidikan ini terjadi proses transfer ilmu pengetahuan, keterampilan, pengajaran sikap dan nilai-nilai moral yang berlaku di 
masyarakat, sehingga dapat melahirkan siswa dengan kepribadian yang matang (Kidd dkk., 2020). Adapun dengan adanya literasi ekonomi digital ini diharapkan para siswa tersebut memahami bagaimana mengelola ekonomi melalui kreativitas, pengetahuan, teknologi sebagai sumber daya utama dalam mendorong perekonomian. Melalui konsep tersebut maka tercetuslah istilah ekonomi kreatif (Ghufron \& Rahmadtullah, 2019).

Konsep ekonomi kreatif ini nyatanya bukan konsep baru dalam perekonomian, karena secara tersirat pada tahun 1911, melalui teori ekonomi pembangunan Schumpeter (1934) menyebutkan teori tentang creative destruction yang berarti penghancuran yang kreatif. Adapun dalam teori tersebut mengandung unsur inovasi dan kemajuan, yang mana untuk masuk dalam perekonomian bisa dilakukan dengan cara-cara yang kreatif sehingga memunculkan sebuah inovasi (Munro, 2017). Maka perusahaan lama yang kurang inovatif akan tergantikan oleh perusahaan baru yang memiliki semangat kewirausahaan. Keadaan tersebut membuat arah pertumbuhan ekonomi menuju kearah yang lebih tinggi. Konsep ekonomi kreatif saat ini terlihat lebih eksplisit, hal tersebut menunjukkan adanya peradaban era baru yang terdeskripsi dengan baik serta berperan sebagai alternatif dalam meningkatkan pertumbuhan ekonomi global di era revolusi industri 4.0 ini. Dalam hal ini konsep ekonomi kreatif dan konsep kewirausahaan memiliki benang merah yang sama, yakni didalamnya mengandung sebuah kreativitas berupa gagasan atau ide sehingga terciptalah sebuah inovasi baru (Ben Youssef dkk., 2021). Kreativitas merupakan sebuah keahlian dalam menyalurkan ide atau gagasan dalam sebuah karya terbaru yang berbeda dari sebelumnya (Sousa dkk., 2019). Seseorang yang memiliki kreativitas, jiwanya akan tertantang untuk membuat karya nyata yang berguna dan dapat dinikmati baik oleh dirinya sendiri maupun orang lain. Sehingga unsur kreativitas sudah menjadi sebuah keharusan untuk disisipkan dalam kurikulum pendidikan, supaya siswa mampu menumbuhkan kreativitas yang dimilikinya.

Dalam sebuah bisnis, kreativitas dapat diterapkan untuk memecahkan masalah yang dihadapi dalam usahanya, baik berupa isu yang berpotensi menjatuhkan atau meningkatkan usahanya, maupun berupa kesempatan atau peluang pada pengembangan bisnisnya. Disisi lain, dalam dunia wirausaha tantangan yang diberikan semakin hari juga semakin kompleks, yang disertai dengan perkembangan industri yang semakin cepat (Treanor dkk., 2021). Kewirausahaan dapat didefinisikan sebagai sebuah proses dalam berbagai aktivitas, yang dapat memberikan pengetahuan atau pemahaman dalam menciptakan kemakmuran bagi individu maupun kelompok masyarakat tertentu (Spivack \& McKelvie, 2021). Menjadi seorang wirausaha haruslah memiliki jiwa yang kreatif dan inovatif, hal ini dimaksudkan sebagai dasar dan sumber daya untuk mencapai peluang menjadi pengusaha yang sukses. Dalam berwirausaha kreativitas yang tinggi sangat diperlukan, akan tetapi sentuhan inovasi juga harus tetap diberikan supaya produk tersebut laku dipasaran. Inovasi yang dimaksud dalam hal ini adalah kemampuan wirausahawan dalam meningkatkan nilai guna atau mutu dari produk yang dikembangkan (Ejdemo \& Örtqvist, 2020).

Dipandang dari sisi subjek sebagai perilaku individual, pada hakikatnya kewirausahaan merupakan sifat, watak maupun ciri khas seseorang dalam mengimplementasikan inovasi dalam dunia nyata secara kreatif (Karami \& Read, 2021). Kreativitas tersebut muncul karena dilandasi oleh pola pikir yang maju, penuh gagasan serta mampu memiliki daya pembeda terhadap produk yang ada dipasaran. Gagasan yang muncul dalam diri wirausahawan sebenarnya tidak dapat dibatasi oleh ruang dan waktu, bahkan gagasan tersebut biasanya muncul dan kelihatan mustahil untuk diimplementasikan. Namun sebaik apapun gagasan 
tersebut, apabila tidak diimplementasikan maka sampai kapanpun juga hanya menjadi gagasan saja. Dengan demikian, maka literasi ekonomi digital dipandang cukup penting untuk diberikan pada siswa, supaya gagasan yang dimiliki tersebut dapat diimplementasikan dengan baik. Adapun tujuan dalam penulisan artikel ini adalah untuk mengetahui peran literasi ekonomi digital terhadap motivasi siswa dalam berwirausaha.

\subsection{Literasi Ekonomi}

Literasi ekonomi adalah masalah yang sangat krusial bagi individu. Hal ini disebabkan karena literasi ekonomi mendorong perilaku ekonomi. Literasi dalam hal keyakinan subjektif disebutkan bahwa seseorang memiliki kemungkinan respon terhadap banyak pertanyaan, dan distribusi keyakinan subjektif, bukan hanya jawaban untuk pertanyaan benar-salah atau pilihan ganda (Tovazzi dkk., 2020). Selain itu, literasi juga dapat digunakan sebagai tolak ukur untuk mengukur keyakinan bahwa seseorang mengetahui fakta (Remund, 2010). Sehingga dapat dikatakan bahwa literasi ekonomi merupakan karakteristik esensial dari perilaku ekonomi (Potrich \& Vieira, 2018). Literasi ekonomi diperlukan bagi semua warga negara dalam menentukan pilihan sebagai sumber pendapatan dan alternatif pilihan bagi konsumen (Lusardi \& Mitchell, 2014). Artinya, pembelajaran ekonomi tidak dapat dibatasi pada kelompok siswa tertentu, seperti angkatan kerja atau bagi mereka yang akan menjadi pemimpin pemerintahan di masa depan saja, tetapi perguruan tinggi juga harus membekali mahasiswanya tentang ekonomi dan bisnis.

Literasi ekonomi sangat penting di semua negara untuk mempersiapkan siswa menghadapi perubahan sistem keuangan dunia (Jappelli, 2010). Siswa akan membutuhkan lebih banyak pemahaman tentang ekonomi untuk berpartisipasi secara aktif dalam perubahan ekonomi global. Berdasarkan uraian literasi ekonomi terlihat bahwa literasi ekonomi terdiri dari dua aspek. Pertama, aspek pengetahuan ekonomi dan sikap ekonomi merupakan turunan dari pemahaman mata pelajaran ekonomi dari berbagai literatur (Happ dkk., 2016). Literasi ekonomi sendiri bukanlah tujuan melainkan alat untuk mencapai tujuan (Nurjanah dkk., 2018).

\subsection{Literasi Digital}

Literasi digital mengacu pada keterampilan yang diperlukan untuk menavigasi teknologi jaringan dan menafsirkan makna pesan digital (Moreno-Morilla dkk., 2021). Literasi tersebut melibatkan kegiatan pencarian di web, menganalisis secara kritis isi yang terkandung, serta menggunakan media berupa alat tertentu untuk mencapai tujuan (Setiyadi dkk., 2019). Melek internet sering kali juga disebut-sebut sebagai konsep literasi digital. Namun melek internet ini terbatas pada penggunaan berbagai sumber informasi yang dicari dengan tujuan tertentu. Pada literasi digital, didalamnya mencakup elemen kreasi, akses dan interpretasi dari media digital (Szymkowiak dkk., 2021).

Lebih lanjut, literasi digital ini juga termasuk bentuk ketertarikan seseorang dalam menggunakan berbagai teknologi seperti komputer, laptop, smartphone dan berbagai teknologi lainnya untuk mengakses berbagai informasi (Moreno-Morilla dkk., 2021). Informasi tersebut selanjutnya dapat dijadikan sebagai pengetahuan baru supaya dapat berpartisipasi secara aktif dalam masyarakat yang saat ini sudah mulai melek digital. Penggunaan kompetensi digital dalam kehidupan sehari-hari telah mendefinisi ulang konsep tradisional, 
menyoroti koeksistensi dari banyaknya ruang fisik dan virtual. Literasi digital didalamnya juga mencakup penciptaan ruang baru yakni sebuah ruang yang digunakan untuk interaksi sosial melalui penggunaan media dan jaringan (Trisiana, 2020). Dalam proses pembelajaran, ruang virtual juga diciptakan yang mana didalamnya banyak melibatkan penggunaan teknologi informasi dan komunikasi.

\subsection{Perilaku Berwirausaha}

Perilaku berwirausaha pada umumnya mengacu pada perilaku yang ditetapkan selama proses berwirausaha (Cai dkk., 2018). Penelitian tentang kewirausahaan berkaitan dengan pengembangan peluang dan pengembangan sumber daya, di mana peluang adalah inti dari proses kewirausahaan dan sumber daya membuktikan keamanan dasarnya (Schickinger dkk., 2021). Penelitian tentang teori kewirausahaan dibagi menjadi dua kerangka utama yakni kewirausahaan yang didominasi peluang dan sumber daya. Pengenalan dan eksploitasi peluang merupakan bagian terpenting dari proses kewirausahaan, dan pengenalan peluang biasanya merupakan perilaku kewirausahaan di awal mengembangkan usaha (Gieure dkk., 2020). Sementara itu, usaha baru harus bisa mengintegrasikan sumber daya untuk membangun kemampuan dalam beradaptasi dengan lingkungan eksternal, hal tersebut dimaksudkan untuk mengatasi risiko dan peluang, yang menekankan peran penting pengembangan sumber daya (Gurău \& Dana, 2020).

Perilaku berwirausaha juga mengacu pada serangkaian tindakan dimana suatu perusahaan mengembangkan sumber daya secara kreatif untuk mengejar peluang, dan menyadari nilai peluang (Udimal dkk., 2020). Pengembangan peluang kewirausahaan dan pengembangan sumber daya sulit dipisahkan; evaluasi peluang dapat dicapai berdasarkan pengakuan sumber daya, sementara akuisisi dan integrasi sumber daya ada di seluruh proses pengembangan peluang dan memungkinkan untuk mengeksploitasi peluang dengan sukses (Lassalle dkk., 2020). Berdasarkan perspektif terintegrasi pada proses kewirausahaan, maka hubungan antara peluang dan sumber daya berkembang sebagai proses interaksi yang kompleks dan dinamis, dan dengan demikian perilaku berwirausaha adalah bentuk perilaku pengembangan yang terintegrasi dengan sumber daya peluang yang sistematis (Bartie dkk., 2021).

\section{Metode}

Penelitian ini dilakukan sebagai upaya untuk mendeskripsikan peran literasi ekonomi digital terhadap motivasi siswa untuk berwirausaha. Adapun dalam penelitian yang dilakukan oleh peneliti ini menggunakan metode studi pustaka, dimana temuan dan teori dari penelitian terdahulu digunakan sebagai dasar dalam menyusun artikel. Selain itu, informasi juga diperoleh dari sumber terpercaya yang berhubungan dengan literasi ekonomi, literasi digital, dan perilaku berwirausaha. Selanjutnya data yang diperoleh tersebut dianalisis atau dikaji secara mendalam dan terperinci sesuai dengan topik yang dibahas dengan memberikan penjelasan secara sistematis, logis, spesifik, dan konkret. Peneliti menggunakan teknik analisis isi dalam menyusun artikel, yang mana teknik ini telah digunakan dan diterima untuk melakukan penelitian secara luas dalam ilmu sosial (Piccarozzi dkk., 2021).

\section{Hasil dan Pembahasan}

Literasi ekonomi sangat penting untuk diberikan pada siswa, semakin tinggi literasi ekonomi seseorang, maka pola pikir seseorang dalam berwirausaha semakin rasional 
(Anthony dkk., 2015). Dalam hal ini literasi ekonomi yang diberikan meliputi sikap, pengetahuan, dan keterampilan dalam mengelola ekonomi yang berkaitan dengan kehidupan sehari-hari (Di Girolamo dkk., 2015). Pada dasarnya literasi ekonomi memiliki benang merah yang kuat dengan kegiatan wirausaha. Perilaku berwirausaha adalah serangkaian aktivitas yang dikembangkan oleh seseorang untuk menggunakan sumber daya secara kreatif dan mengejar peluang dalam rangka mewujudkan terciptanya suatu nilai (Neneh, 2019). Para wirausahawan menyajikan perilaku pembangunan yang terintegrasi dengan peluang dalam konteks industri yang sedang berkembang. Peluang dan sumber daya merupakan suatu hal yang tidak dapat dipisahkan (Udimal dkk., 2020). Seseorang yang memiliki jiwa usaha menemukan peluang berdasarkan sumber daya yang mereka miliki yang selanjutnya diintegrasikan dengan sumber daya jaringan sosial mereka. Beralihnya perdagangan secara kontak fisik menuju perdagangan melalui dunia maya, konsumen semakin sering melakukan aktivitas secara online (S. Elia dkk., 2021). Pergeseran tersebut telah menghasilkan peluang baru bagi wirausahawan yang menggunakan teknologi digital untuk mendapatkan keuntungan pada usaha yang dikembangkannya (Jafari-Sadeghi dkk., 2021).

Pada masyarakat umum, literasi bermakna sebagai sesuatu yang berkaitan dengan kegiatan membaca (Smalle dkk., 2019). Akan tetapi dalam hal ini literasi ekonomi berarti kemampuan seseorang dalam memahami proses ekonomi, sehingga lama kelamaan dari pemahaman tersebut membuat seseorang mampu menentukan pilihan yang tepat sesuai dengan alokasi sumber daya yang ada (Tovazzi dkk., 2020). Literasi ekonomi pada dasarnya tidak hanya untuk siswa saja, akan tetapi merupakan bagian dari salah satu kemampuan yang harus dimiliki oleh setiap orang. Dalam hal ini literasi ekonomi meliputi kesadaran seseorang tentang bagaimana dan mengapa harus menjadi konsumen yang pintar, produsen yang cakap, investor yang bijak, serta bagaimana menjadi seorang warga negara yang baik dan bertanggung jawab (Potrich \& Vieira, 2018).

Literasi ekonomi sebagai salah satu bentuk untuk memberikan kemampuan memahami proses ekonomi, didalamnya mengandung salah satu unsur tentang bagaimana memanfaatkan sumber daya berupa uang dengan sebaik mungkin (Lusardi \& Mitchell, 2014). Sehingga banyak dari masyarakat yang menganggap sama antara literasi ekonomi dengan literasi finansial (Razen dkk., 2021). Pernyataan tersebut tidak sepenuhnya salah, karena pada dasarnya literasi finansial sudah menjadi bagian yang tidak terpisahkan dari literasi ekonomi. Dalam pengambilan sebuah keputusan literasi ekonomi tentu ikut andil didalamnya, karena literasi ekonomi menjadi sebuah kekuatan personal dan sebagai bentuk partisipasi aktif dalam masyarakat untuk membantu pertumbuhan ekonomi suatu negara (Sequeira, 2021). Sehingga ketika seseorang ingin mencapai kesejahteraan, maka literasi ekonomi penting untuk dipahami.

Melihat pentingnya literasi ekonomi ini, maka terdapat beberapa alasan seseorang harus meningkatkan kemampuannya di bidang ekonomi melalui literasi, diantaranya adalah sebuah pernyataan yang menyebutkan bahwa setiap manusia hidup adalah seorang ekonom (Habibi \& Zabardast, 2020). Dimana untuk memenuhi kebutuhan hidupnya, maka manusia akan berfikir secara rasional untuk mencapai kesejahteraan baik di masa sekarang maupun dimasa mendatang. Selain itu, alasan lain yang mendasarinya adalah bahwa dalam hidup manusia harus membuat pilihan diantara berbagai alternatif, sehingga literasi ekonomi diberikan supaya manusia dapat menentukan pilihan yang tepat atas berbagai alternatif yang ada (Murniatiningsih, 2017). 
Dalam menanggapi revolusi industri 4.0 yang menyebabkan pesatnya perkembangan teknologi digital (Solomon \& van Klyton, 2020), literasi ekonomi dihadirkan tidak hanya sebagai pedoman, namun keduanya memiliki relevansi dimana literasi ekonomi dapat menjadi substansi dari media digital, sehingga lahirlah istilah literasi ekonomi digital. Literasi digital dimaksudkan untuk mengarahkan seseorang dalam memahami, menguraikan, menyimpulkan dan memanfaatkan informasi dari dunia digital (Wahbi \& Ariwibowo, 2019). Sehingga ketika literasi ekonomi digital telah dipahami maka aktivitas ekonomi yang dihasilkan dapat dilakukan melalui miliaran koneksi internet antara orang, bisnis, perangkat, data, dan proses. Tulang punggung ekonomi digital adalah hyperconnectivity yang berarti meningkatnya keterkaitan orang, organisasi, dan mesin yang dihasilkan dari Internet, teknologi seluler, dan internet of things (IoT). Ekonomi digital mulai terbentuk dan merongrong gagasan konvensional tentang bagaimana bisnis disusun, bagaimana perusahaan berinteraksi, dan bagaimana konsumen memperoleh layanan, informasi, dan barang. Digitalisasi ekonomi menciptakan manfaat dan efisiensi karena teknologi digital mendorong inovasi dan mendorong peluang kerja dan pertumbuhan ekonomi. Ekonomi digital juga merembes ke semua aspek masyarakat, mempengaruhi cara orang berinteraksi dan membawa perubahan sosiologis yang luas (Mohamed, 2020).

Baru-baru ini, TechCrunch, situs berita ekonomi digital mencatat bahwa perusahaan taksi terbesar di dunia yakni Uber, tidak memiliki kendaraan. Facebook, pemilik media paling populer di dunia, tidak membuat konten. Alibaba, pengecer paling berharga tidak memiliki inventaris. Dan Airbnb, penyedia akomodasi terbesar di dunia, tidak memiliki real estate, dari contoh-contoh tersebut telah menunjukkan bahwa penggunaan data yang yang tepat mampu mengubah model bisnis, memfasilitasi produk dan layanan baru, menciptakan proses baru, menghasilkan utilitas yang lebih besar, dan mengantarkan budaya manajemen baru. Dalam ekonomi digital, semua pelanggan, pelaku bisnis, maupun produsen, ingin selalu bisa berinteraksi dengan produk bisnisnya kapan dan dimanapun mereka berada melalui cara yang paling nyaman bagi mereka. Selain itu, pelanggan menginginkan keterlibatan dengan merek melalui pengalaman yang mulus, langsung, kontekstual, dan dipersonalisasi. Sehingga menjadi penting untuk memberikan semua pelanggan perjalanan yang dipersonalisasi dan unik dari saat mereka tiba di situs web bisnis hingga melakukan pembelian di toko online tersebut.

Memahami ekonomi digital tetap menjadi tantangan karena kompleksitasnya. Transformasi digital tidak hanya tentang big data dan platform digital tetapi juga bagaimana teknologi canggih tersebut dapat digunakan untuk memaksimalkan peluang inovasi, model dan proses bisnis baru, serta produk dan layanan pintar. Lebih lanjut, ekonomi digital memungkinkan bisnis regional untuk menjauh dari lokal dan global, sejalan dengan tren jangka panjang menuju liberalisasi pasar dan pengurangan hambatan perdagangan (Habibi \& Zabardast, 2020). Ekonomi digital sedang berkembang ini memiliki potensi untuk menghasilkan penelitian dan terobosan ilmiah baru, mendorong peluang kerja, pertumbuhan ekonomi, dan meningkatkan cara orang menjalani kehidupan yang sejahtera (Mohamed, 2020).

Salah satu tren makro utama yang terjadi saat ini dan sangat menarik adalah fenomena kewirausahaan dan berkembangnya perusahaan rintisan digital, di mana tingkat inovasi yang dikembangkan sangat memudahkan pekerjaan manusia (Yoganandan \& Dinesh Kumar, 2021). Saat ini banyak industri yang mulai beradaptasi dengan teknologi baru dan hal ini dimanifestasikan oleh tren penting seperti adopsi cloud dan data besar di dalam perusahaan 
besar, IoT dan seluler yang mempengaruhi ruang berbeda, serta kemajuan dalam kecerdasan buatan yang dilakukan oleh mesin (Otache dkk., 2021). Fenomena yang lebih luas di sekitar era inovasi dan kewirausahaan ini kemudian bermanifestasi menjadi beberapa tren inti yang berada pada titik perubahan yang sangat bagus untuk diadopsi di dalam perusahaan besar. Mungkin satu-satunya peluang terbesar yang dapat melihat adalah adanya konektivitas digital umum antara sistem yang terisolasi secara historis, yang selanjutnya berpindah dari sistem lama yang terisolasi ke aplikasi berbasis cloud yang memungkinkan aliran data dan informasi yang lebih efektif, serta kolaborasi di seluruh organisasi. Didukung oleh konektivitas, teknologi cloud memungkinkan bisnis lebih dirampingkan lagi prosesnya dengan cara yang hemat biaya dan andal, selain itu juga menawarkan fleksibilitas yang diperlukan untuk menskalakan operasi dan menyesuaikan dengan permintaan.

Bagi calon wirausaha digital, konektivitas dan cloud sangat penting karena memungkinkan mereka untuk berkolaborasi dan mengakses sumber daya dari lokasi mana pun dengan jaringan yang aman (Fossen \& Sorgner, 2021). Artinya mereka dapat bekerja secara efektif tanpa harus berinvestasi di ruang kantor fisik. Hal ini mengurangi biaya awal, memberikan peluang bagi bisnis kecil dan pemula untuk bersaing dengan perusahaan besar yang memiliki anggaran lebih besar, yang pada akhirnya meningkatkan level permainan. Karenanya, meningkatkan akses konektivitas menjadi kunci untuk mengembangkan ekonomi digital (Leong dkk., 2020).

Tidak dapat disangkal bahwa ekspektasi pelanggan berubah di seluruh dunia, dan kita akan melihat hal ini semakin hari semakin meningkat. Baik konsumen baru maupun konsumen lama akan lebih bergantung pada konektivitas internet untuk melakukan pembelian, mendorong hasil bisnis, supaya tetap terhubung dengan dunia di sekitar mereka. Inti dari ekonomi digital adalah konektivitas, dan konektivitas yang andal merupakan prasyarat untuk bergabung dengan ekonomi digital. Para pengusaha maupun calon pengusaha dapat membantu mengubah bagaimana cara memproduksi dan memberi pelayanan dengan baik, mengoptimalkan dan menggunakan layanan digital dengan baik, serta menggunakan beberapa cara untuk promosi supaya orang lain mengetahui merek dan produk mereka. Jika seseorang ingin mengembangkan sebuah usaha, penting untuk diingat bahwa saat ini banyak calon konsumen yang menggunakan alat digital, sehingga seorang pengusaha harus menyesuaikan hal itu.

Ada berbagai cara bagi wirausahawan untuk bergabung dengan ekonomi digital, hal ini bisa dimulai dengan melewati struktur bisnis tradisional dan menyelaraskan kembali penciptaan nilai suatu produk (G. Elia dkk., 2020). Namun, ini bukan berarti memikirkan kembali semua aspek penawaran produk yang ada, tetapi lebih berfokus pada peralihan dari interaksi dan operasi fisik ke operasi digital yang akan memungkinkan model bisnis dan layanan baru. Dalam hal ini yang dibutuhkan adalah strategi integrasi yang mempertimbangkan struktur dan proses fisik yang ada dan mengintegrasikannya dengan sistem digital. Keterlibatan pelanggan multisaluran, memungkinkan wirausahawan untuk memvisualisasikan siklus hidup pelanggan yang sebenarnya dan membantu mengidentifikasi celah atau kelemahan. Hal ini memberi pengusaha kesempatan unik untuk mengidentifikasi peluang, merespons peluang dengan cepat, dan mengembangkan ekonomi baru. Tingkat kelincahan inilah yang akan membantu wirausahawan menciptakan dan memberikan layanan dan produk yang lebih selaras dengan keinginan dan kebutuhan pelanggan, membantu menumbuhkan ekonomi digital, dan mengembangkan ekonomi yang lebih luas. 
Di dunia digital baru yang sangat kompetitif ini, para wirausahawan perlu menilai apakah layanan yang mereka tawarkan benar-benar menambah nilai dengan cara yang seefisien mungkin atau sebaliknya (Cai dkk., 2018). Seiring dengan pertumbuhan ekonomi digital, seseorang akan melihat lebih banyak pesaing baru menggunakan berbagai alat digital untuk membawa berbagai layanan dan berbagai produk ke pasar dengan lebih cepat. Persaingan yang kompetitif dalam ekosistem tersebut membutuhkan kombinasi, konektivitas, pemikiran inovatif, dan kemitraan yang cerdas untuk membantu membedakan bisnis yang dikembangkan. Akan tetapi, seperti yang ditunjukkan oleh perusahaan raksasa yang berskala internasional, seperti Amazon dan Alphabet, bagi perusahaan yang melakukannya dengan benar, ekonomi digital akan menawarkan peluang yang belum pernah terjadi sebelumnya.

Pendidikan dan ekonomi digital pasti akan memainkan peran besar di masa depan. Mirip dengan bagaimana pendidikan merupakan aspek kunci di masa depan bagi setiap calon siswa. Miliaran koneksi online yang dibuat oleh berbagai bidang pendidikan membuat hubungan antara pendidikan dan ekonomi digital menjadi sangat kuat. Teknologi yang ada seharusnya dapat mendukung pendidikan apabila digunakan secara efektif, disisi lain juga dapat memberikan efek positif pada pengalaman belajar siswa. Ekonomi digital memberikan pengalaman pada siswa sesuatu yang tak ternilai serta dapat dengan mudah untuk mencari pekerjaan dan membangun jaringan.

Seseorang yang ingin berhasil dalam dunia bisnis sangat membutuhkan keterampilan digital karena ekonomi global menuntut adanya keterampilan tersebut. Begitu juga untuk siswa di seluruh dunia juga membutuhkan keterampilan tersebut karena tuntutan perkembangan teknologi yang tidak dapat terbendung. Nilai ekonomi digital inilah yang menjadikannya bagian penting dari pendidikan. Selanjutnya, pendidikan dan ekonomi digital memiliki nilai luar biasa bagi banyak program akademik, baik bagi siswa maupun mahasiswa. Salah satu strategi terpenting terkait pendidikan dan ekonomi digital adalah teknologi informasi dan komunikasi (TIK), dalam hal ini TIK lebih mengedepankan inovasi dengan memanfaatkan teknologi (G. Elia dkk., 2016). Hal ini membantu siswa mengatasi masalah yang lebih kompleks dengan berbagai perspektif yang berpikiran digital.

Tren jual beli online nyatanya makin digemari oleh berbagai kalangan, baik oleh ibu rumah tangga maupun anak muda (Harahap, 2018). Bahkan para pelajar juga banyak yang mengikuti tren tersebut. Hal ini dikarenakan banyaknya kemudahan yang ditawarkan di dalamnya, sehingga membuat para pelajar tidak malu untuk ikut serta menjadi wirausaha muda. Melalui literasi ekonomi digital yang diberikan kepada siswa, nyatanya mampu memotivasi siswa untuk ikut serta dalam berwirausaha (Seprina dkk., 2018). Meskipun dalam hal ini para siswa baru belajar dengan modal yang seadanya. Melalui literasi ekonomi digital ini, setidaknya para siswa dituntut untuk memahami bagaimana memanfaatkan teknologi digital dalam kegiatan ekonomi, supaya memperoleh keuntungan yang diharapkan (Trihudiyatmanto, 2019). Materi kewirausahaan yang diberikan pada siswa tentang bagaimana membuka toko digital serta membeli produk dari produsen nyatanya cukup menyenangkan bagi siswa, karena siswa selama ini sudah terbiasa dengan teknologi digital. Dalam hal ini literasi ekonomi digital berfungsi sebagai media dalam mengembangkan potensi yang ada pada siswa, terkait kemampuannya dalam mengembangkan usaha yang sesuai dengan passion atau bidang yang disukainya. Sehingga berdasarkan penelitian-penelitian yang dilakukan sebelumnya seperti penelitian oleh (Harahap, 2018; Seprina dkk., 2018; Trihudiyatmanto, 2019) diharapkan kedepannya banyak anak muda yang mampu 
mengembangkan usahanya masing-masing, dengan memaksimalkan pengembangan digital supaya kegiatan usaha berjalan dengan efektif dan efisien.

\section{Simpulan}

Berdasarkan pemaparan diatas dapat disimpulkan bahwasannya literasi ekonomi sangat penting untuk diberikan pada siswa, semakin tinggi literasi ekonomi seseorang, maka pola pikir seseorang dalam berwirausaha semakin rasional. Disisi lain literasi digital juga penting untuk diberikan, mengingat perkembangan teknologi yang semakin pesat ini tentunya juga harus dibarengi dengan persiapan-persiapan yang matang pada siswa. Dalam hal ini yakni berupa keterampilan dalam berwirausaha dengan memanfaatkan informasi yang diperoleh secara digital. Berdasarkan beberapa penelitian sebelumnya disebutkan bahwa perkembangan electronic commerce atau perdagangan secara elektronik mampu meningkatkan minat siswa dalam berwirausaha. Hal ini dikarenakan banyak kemudahan yang diberikan terhadap pengembangan teknologi perdagangan tersebut. Diharapkan melalui literasi ekonomi digital yang diberikan pada siswa, kedepannya banyak siswa yang dapat mengembangkan usahanya, sehingga mampu meminimalisir pengangguran.

\section{Daftar Rujukan}

Alam, G. M., Forhad, A. R., \& Ismail, I. A. (2020). Can education as an 'International Commodity' be the backbone or cane of a nation in the era of fourth industrial revolution? - A Comparative study. Technological Forecasting and Social Change, 159, 120184. https://doi.org/10.1016/j.techfore.2020.120184

Anggreini, C., \& Waspada, I. (2020). Kajian Literasi Ekonomi Siswa Sekolah Menengah Atas Al-Amanah Ciwidey. 2(1), 9. http://dx.doi.org/10.29300/ijsse.v2i1.2731

Anthony, K. V., Smith, R. C., \& Miller, N. C. (2015). Preservice elementary teachers' economic literacy: Closing gates to full implementation of the social studies curriculum. The Journal of Social Studies Research, 39(1), 29-37. https://doi.org/10.1016/j.jssr.2014.04.001

Aziz Hussin, A. (2018). Education 4.0 Made Simple: Ideas For Teaching. International Journal of Education and Literacy Studies, 6(3), 92. https://doi.org/10.7575/aiac.ijels.v.6n.3p.92

Bartie, N. J., Cobos-Becerra, Y. L., Fröhling, M., Schlatmann, R., \& Reuter, M. A. (2021). The resources, exergetic and environmental footprint of the silicon photovoltaic circular economy: Assessment and

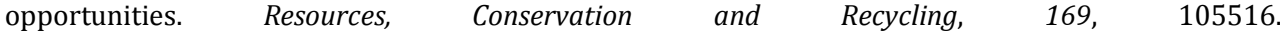
https://doi.org/10.1016/j.resconrec.2021.105516

Ben Youssef, A., Boubaker, S., Dedaj, B., \& Carabregu-Vokshi, M. (2021). Digitalization of the economy and entrepreneurship intention. Technological Forecasting and Social Change, 164, 120043. https://doi.org/10.1016/j.techfore.2020.120043

Berawi, M. A. (2019). Managing Nature 5.0 in Industrial Revolution 4.0 and Society 5.0 Era. International Journal of Technology, 10(2), 222. https://doi.org/10.14716/ijtech.v10i2.3084

Bilotta, E., Bertacchini, F., Gabriele, L., Giglio, S., Pantano, P. S., \& Romita, T. (2020). Industry 4.0 technologies in tourism education: Nurturing students to think with technology. Journal of Hospitality, Leisure, Sport \& Tourism Education, 100275. https://doi.org/10.1016/j.jhlste.2020.100275

Cai, L., Peng, X., \& Wang, L. (2018). The characteristics and influencing factors of entrepreneurial behaviour: The case of new state-owned firms in the new energy automobile industry in an emerging economy. Technological Forecasting and Social Change, 135, 112-120. https://doi.org/10.1016/j.techfore.2018.04.014

Di Girolamo, A., Harrison, G. W., Lau, M. I., \& Swarthout, J. T. (2015). Subjective belief distributions and the characterization of economic literacy. Journal of Behavioral and Experimental Economics, 59, 1-12. https://doi.org/10.1016/j.socec.2015.08.004

Ejdemo, T., \& Örtqvist, D. (2020). Related variety as a driver of regional innovation and entrepreneurship: A moderated and mediated model with non-linear effects. Research Policy, 49(7), 104073. https://doi.org/10.1016/j.respol.2020.104073 
Elia, G., Margherita, A., \& Passiante, G. (2020). Digital entrepreneurship ecosystem: How digital technologies and collective intelligence are reshaping the entrepreneurial process. Technological Forecasting and Social Change, 150, 119791. https://doi.org/10.1016/j.techfore.2019.119791

Elia, G., Margherita, A., \& Petti, C. (2016). An Operational Model to Develop Technology Entrepreneurship “EGOSystem." International Journal of Innovation and Technology Management, 13(05), 1640008. https://doi.org/10.1142/S0219877016400083

Elia, S., Giuffrida, M., Mariani, M. M., \& Bresciani, S. (2021). Resources and digital export: An RBV perspective on the role of digital technologies and capabilities in cross-border e-commerce. Journal of Business Research, 132, 158-169. https://doi.org/10.1016/j.jbusres.2021.04.010

Fossen, F. M., \& Sorgner, A. (2021). Digitalization of work and entry into entrepreneurship. Journal of Business Research, 125, 548-563. https://doi.org/10.1016/j.jbusres.2019.09.019

Fukuda, K. (2019). Science, technology and innovation ecosystem transformation toward society 5.0. International Journal of Production Economics, 107460. https://doi.org/10.1016/j.ijpe.2019.07.033

Ghufron, M. I., \& Rahmadtullah, M. (2019). Peran Ekonomi Kreatif sebagai Solusi Mengatasi Pengangguran. Derivatif: Jurnal Manajemen 13(1), 12.

Gieure, C., Benavides-Espinosa, M. del M., \& Roig-Dobón, S. (2020). The entrepreneurial process: The link between intentions and behavior. Journal of Business Research, 112, 541-548. https://doi.org/10.1016/j.jbusres.2019.11.088

Gladden, M. E. (2019). Who Will Be the Members of Society 5.0? Towards an Anthropology of Technologically Posthumanized Future Societies. Social Sciences, 8(5), 148. https://doi.org/10.3390/socsci8050148

Grunwitz, K. (2019). The future is Society 5.0. Computer Fraud \& Security, 2019(8), 20. https://doi.org/10.1016/S1361-3723(19)30087-9

Gurău, C., \& Dana, L.-P. (2020). Financing paths, firms' governance and corporate entrepreneurship: Accessing and applying operant and operand resources in biotechnology firms. Technological Forecasting and Social Change, 153, 119935. https://doi.org/10.1016/j.techfore.2020.119935

Habibi, F., \& Zabardast, M. A. (2020). Digitalization, education and economic growth: A comparative analysis of Middle East and OECD countries. Technology in Society, 63, 101370. https://doi.org/10.1016/j.techsoc.2020.101370

Happ, R., Förster, M., Zlatkin-Troitschanskaia, O., \& Carstensen, V. (2016). Assessing the previous economic knowledge of beginning students in Germany: Implications for teaching economics in basic courses. $\begin{array}{llll}\text { Citizenship, Social and Economics } & \text { Education, }\end{array}$ https://doi.org/10.1177/2047173416646597

Harahap, D. A. (2018). Perilaku Belanja Online di Indonesia: Studi Kasus. JRMSI - Jurnal Riset Manajemen Sains Indonesia, 9(2), 193-213. https://doi.org/10.21009/JRMSI.009.2.02

Jafari-Sadeghi, V., Garcia-Perez, A., Candelo, E., \& Couturier, J. (2021). Exploring the impact of digital transformation on technology entrepreneurship and technological market expansion: The role of technology readiness, exploration and exploitation. Journal of Business Research, 124, 100-111. https://doi.org/10.1016/j.jbusres.2020.11.020

Jappelli, T. (2010). Economic Literacy: An International Comparison. The Economic Journal, 120(548), F429F451. https://doi.org/10.1111/j.1468-0297.2010.02397.x

Karami, M., \& Read, S. (2021). Co-creative entrepreneurship. Journal of Business Venturing, 36(4), 106125. https://doi.org/10.1016/j.jbusvent.2021.106125

Kidd, D., Miner, J., Schein, M., Blauw, M., \& Allen, D. (2020). Ethics across the curriculum: Detecting and describing emergent trends in ethics education. Studies in Educational Evaluation, 67, 100914. https://doi.org/10.1016/j.stueduc.2020.100914

Lassalle, P., Johanson, M., Nicholson, J. D., \& Ratajczak-Mrozek, M. (2020). Migrant entrepreneurship and markets: The dynamic role of embeddedness in networks in the creation of opportunities. Industrial Marketing Management, 91, 523-536. https://doi.org/10.1016/j.indmarman.2020.04.009

Leong, C., Tan, F. T. C., Tan, B., \& Faisal, F. (2020). The emancipatory potential of digital entrepreneurship: A study of financial technology-driven inclusive growth. Information \& Management, 103384. https://doi.org/10.1016/j.im.2020.103384 
Lusardi, A., \& Mitchell, O. S. (2014). The Economic Importance of Financial Literacy: Theory and Evidence. Journal of Economic Literature, 52(1), 5-44. https://doi.org/10.1257/jel.52.1.5

Mohamed, H. (2020). Implementing a Central Bank Issued Digital Currency with Economic Implications Considerations. International Journal of Islamic Economics and Finance (IJIEF), 3(1). https://doi.org/10.18196/ijief.2121

Moreno-Morilla, C., Guzmán-Simón, F., \& García-Jiménez, E. (2021). Digital and information literacy inside and outside Spanish primary education schools. Learning, Culture and Social Interaction, 28, 100455. https://doi.org/10.1016/j.lcsi.2020.100455

Mourtzis, D., Angelopoulos, J., \& Dimitrakopoulos, G. (2020). Design and development of a flexible manufacturing cell in the concept of learning factory paradigm for the education of generation 4.0 engineers. Procedia Manufacturing, 45, 361-366. https://doi.org/10.1016/j.promfg.2020.04.035

Munro, E. (2017). Building soft skills in the creative economy: Creative intermediaries, business support and the 'soft skills gap". Poetics, 64, 14-25. https://doi.org/10.1016/j.poetic.2017.07.002

Murniatiningsih, E. (2017). Pengaruh Literasi Ekonomi Siswa, Hasil Belajar Ekonomi, Dan Teman Sebaya Terhadap Perilaku Konsumsi Siswa Smp Negeri Di Surabaya Barat. JURNAL EKONOMI PENDIDIKAN DAN KEWIRAUSAHAAN, 5(1), 127. https://doi.org/10.26740/jepk.v5n1.p127-156

Neneh, B. N. (2019). From entrepreneurial intentions to behavior: The role of anticipated regret and proactive personality. Journal of Vocational Behavior, 112, 311-324. https://doi.org/10.1016/j.jvb.2019.04.005

Nurjanah, S., Ilma, R. Z., \& Suparno, S. (2018). Effect of Economic Literacy and Conformity on Student Consumptive Behaviour. Dinamika Pendidikan, 13(2), 207. https://doi.org/10.15294/dp.v13i2.18330

Onis, F. N., Hariani, L. S., \& Indawati, N. (2018). Pola Konsumsi: Literasi Ekonomi, Status Sosial Orang Tua dan Teman Sebaya. Jurnal Riset Pendidikan Ekonomi, 3(1). https://doi.org/10.21067/jrpe.v3i1.3809

Otache, I., Edopkolor, J. E., \& Okolie, U. C. (2021). Entrepreneurial self-confidence, perceived desirability and feasibility of hospitality business and entrepreneurial intentions of hospitality management technology students. The International Journal of Management Education, 19(2), 100507. https://doi.org/10.1016/j.ijme.2021.100507

Piccarozzi, M., Silvestri, C., Aquilani, B., \& Cagnetti, C. (2021). Industry 4.0 tools in innovative European firms: Exploring their adoption and communication features through content analysis. Procedia Computer Science, 180, 414-423. https://doi.org/10.1016/j.procs.2021.01.257

Potrich, A. C. G., \& Vieira, K. M. (2018). Demystifying financial literacy: A behavioral perspective analysis. Management Research Review, 41(9), 1047-1068. https://doi.org/10.1108/MRR-08-2017-0263

Razen, M., Huber, J., Hueber, L., Kirchler, M., \& Stefan, M. (2021). Financial literacy, economic preferences, and adolescents' field behavior. Finance Research Letters, 40, 101728. https://doi.org/10.1016/j.frl.2020.101728

Remund, D. L. (2010). Financial Literacy Explicated: The Case for a Clearer Definition in an Increasingly Complex Economy. Journal of Consumer Affairs, 44(2), 276-295. https://doi.org/10.1111/j.17456606.2010.01169.x

Romijn, B. R., Slot, P. L., \& Leseman, P. P. M. (2021). Increasing teachers' intercultural competences in teacher preparation programs and through professional development: A review. Teaching and Teacher Education, 98, 103236. https://doi.org/10.1016/j.tate.2020.103236

Rubach, C., \& Lazarides, R. (2021). Addressing 21st-century digital skills in schools - Development and validation of an instrument to measure teachers' basic ICT competence beliefs. Computers in Human Behavior, 118, 106636. https://doi.org/10.1016/j.chb.2020.106636

Saeidi, P., Saeidi, S. P., Sofian, S., Saeidi, S. P., Nilashi, M., \& Mardani, A. (2019). The impact of enterprise risk management on competitive advantage by moderating role of information technology. Computer Standards \& Interfaces, 63, 67-82. https://doi.org/10.1016/j.csi.2018.11.009

Schickinger, A., Bierl, P. A., Leitterstorf, M. P., \& Kammerlander, N. (2021). Family-related goals, entrepreneurial investment behavior, and governance mechanisms of single family offices: An exploratory study. Journal of Family Business Strategy, 100393. https://doi.org/10.1016/j.jfbs.2020.100393

Schumpeter, J. A. (1934). The Theory of Economic Development: An Inquiry into Profits, Capital, Credits, Interest, and the Business Cycle. (1912/1934). Transaction Publishers. -1982.-January, 1, 244 
Seprina, I., Suroyo, H., \& Komalasari, D. (2018). Pengaruh Efektivitas Penggunaan E-Commerce pada Peningkatan Motivasi Berwirausaha pada Siswa SMK Bina Jaya Palembang. Jurnal Sistem Informasi, 8, 7.

Sequeira, T. N. (2021). Inflation, economic growth and education expenditure. Economic Modelling, 99, 105475. https://doi.org/10.1016/j.econmod.2021.02.016

Setiyadi, R., Kuswendi, U., \& Ristiana, M. G. (2019). Digital Literation Through Online Magazine In Learning Reading Comprehension In Elementary School. PrimaryEdu - Journal of Primary Education, 3(2), 97. https://doi.org/10.22460/pej.v3i2.1426

Smalle, E. H. M., Szmalec, A., Bogaerts, L., Page, M. P. A., Narang, V., Misra, D., Araújo, S., Lohagun, N., Khan, O., Singh, A., Mishra, R. K., \& Huettig, F. (2019). Literacy improves short-term serial recall of spoken verbal but not visuospatial items - Evidence from illiterate and literate adults. Cognition, 185, 144-150. https://doi.org/10.1016/j.cognition.2019.01.012

Solomon, E. M., \& van Klyton, A. (2020). The impact of digital technology usage on economic growth in Africa. Utilities Policy, 67, 101104. https://doi.org/10.1016/j.jup.2020.101104

Sousa, M. J., Carmo, M., Gonçalves, A. C., Cruz, R., \& Martins, J. M. (2019). Creating knowledge and entrepreneurial capacity for HE students with digital education methodologies: Differences in the perceptions of students and entrepreneurs. Journal of Business Research, 94, 227-240. https://doi.org/10.1016/j.jbusres.2018.02.005

Spivack, A. J., \& McKelvie, A. (2021). Measuring addiction to entrepreneurship. Journal of Business Venturing Insights, 15, e00212. https://doi.org/10.1016/j.jbvi.2020.e00212

Suratno, Narmaditya, B. S., \& Wibowo, A. (2021). Family economic education, peer groups and students' entrepreneurial intention: The mediating role of economic literacy. Heliyon, 7(4), e06692. https://doi.org/10.1016/j.heliyon.2021.e06692

Szymkowiak, A., Melović, B., Dabić, M., Jeganathan, K., \& Kundi, G. S. (2021). Information technology and Gen Z: The role of teachers, the internet, and technology in the education of young people. Technology in Society, 65, 101565. https://doi.org/10.1016/j.techsoc.2021.101565

Tarighi, S., \& Shavvalpour, S. (2021). Technological development of E\&P companies in developing countries: An integrative approach to define and prioritize customized elements of technological capability in EOR. Resources Policy, 72, 102051. https://doi.org/10.1016/j.resourpol.2021.102051

Teo, T., Unwin, S., Scherer, R., \& Gardiner, V. (2021). Initial teacher training for twenty-first century skills in the Fourth Industrial Revolution (IR 4.0): A scoping review. Computers \& Education, 170, 104223. https://doi.org/10.1016/j.compedu.2021.104223

Tovazzi, A., Giovannini, S., \& Basso, D. (2020). A New Method for Evaluating Knowledge, Beliefs, and Neuromyths About the Mind and Brain Among Italian Teachers. Mind, Brain, and Education, 14(2), 187198. https://doi.org/10.1111/mbe.12249

Treanor, L., Noke, H., Marlow, S., \& Mosey, S. (2021). Developing entrepreneurial competences in biotechnology early career researchers to support long-term entrepreneurial career outcomes. Technological Forecasting and Social Change, 164,120031. https://doi.org/10.1016/j.techfore.2020.120031

Trihudiyatmanto, M. (2019). Membangun Minat Berwirausaha Mahasiswa Dengan Pengaruh Faktor ECommerce, Pengetahuan Kewirausahaan dan Gender. Jurnal Penelitian dan Pengabdian Kepada Masyarakat UNSIQ, 6(2), 93-103. https://doi.org/10.32699/ppkm.v6i2.678

Trisiana, A. (2020). Digital Literation Models For Character Education In Globalization Era: Digital Literation Models. Humanities \& Social Sciences Reviews, 8(1), 522-531. https://doi.org/10.18510/hssr.2020.8164

Udimal, T. B., Luo, M., Liu, E., \& Mensah, N. O. (2020). How has formal institutions influenced opportunity and necessity entrepreneurship? The case of brics economies. Heliyon, 6(9), e04931. https://doi.org/10.1016/j.heliyon.2020.e04931

Wahbi, A. A., \& Ariwibowo, P. (2019). Konsep Literasi Ekonomi Digital: Analisa Dampak Teknologi Terhadap Prilaku Gaya Hidup Guru Smp Se-Tangerang Selatan. Ad-Deenar: Jurnal Ekonomi dan Bisnis Islam, 3(01), $37-44$

Yoganandan, G., \& Dinesh Kumar, M. (2021). Qualities of successful entrepreneurs - A review of relevant literature. Materials Today: Proceedings, $\quad$ S2214785321020113. https://doi.org/10.1016/j.matpr.2021.03.022 